DOI https://doi.org/10.32782/2305-9389/2020.22.16

УДК 351

Грицишен Димитрій,

доктор економічних наук, професор, професор кафедри економічної безпеки, публічного управління та адміністрування Державного університету «Житомирська політехніка»

Прокопенко Жанна, кандидат економічних наук, доцент кафедри економічної безпеки, публічного управління та адміністрування Державного університету «Житомирська політехніка»

Кочин Тетяна, аспірант кафедри обліку і аудиту Державного університету «Житомирська політехніка»

Опанасюк Андрій, здобувач кафедри інформаційних систем в управлінні та обліку Державного університету «Житомирська політехніка»

\title{
РОЗВИТОК АУДИТУ ЯК ІНСТРУМЕНТУ ПРОТИДІЇ ФАЛЬСИФІКАЦІЯМ
}

У статті доведено, щео аналіз сучасного етапу розвитку аудиторської діяльності у світі вказує на відсутність єдиних глобальних підходів до регулювання аудиторської діяльності. Охарактеризовано, щзо кожна країна розробляє свої власні підходи до управління регулюванням аудиту та встановлює конкретні вимоги до діяльності аудиторських фірм. Відзначено, шуо основними характеристиками сучасного аудиту є встановлення вимог до людських ресурсів аудиторської фірми. Доведено, щзо фактично сьогодні аудиторський звіт (висновок) має підтверджувати якість фінансової звітності як важливого інструменту інформування користувачів для прийняття управлінських рішень. Доведено, щчо за допомогою розширення аудиторських процедур, зокрема використання аналітичних прочедур, можна вести мову про аудиторський звіт (висновок) як складову частину інформаційного ресурсу. Охарактеризовано, щчо інформаційним ресурсом економічної та господарської діяльності виступає сукупність інформації, що міститься у фінансовій звітності та аудиторському звіті (висновку). Доведено, щчо варто переглянути підходи до аудиторського звіту (висновку) та визначити його місие в структурі інформаційного ресурсу.

Уточнено, щу аудиторський звіт можна розглядати з декількох позицій: по-перше, як результат роботи аудитора. У даному контексті варто також визначати аудиторський висновок я результат виконання договірних відносин щзодо аудиту фінансової звітності; по-друге, документ, щзо містить думку аудитора щъодо фінансової звітності досліджуваного підприємства та гарантує надання впевненості зацікавленим користувачам. Доведено, щчо варто змінити підхід до аудиторського звіту (висновку) як до документу, щцо підтверджує достовірність показників фінансової звітності, адже зміна запитів користувачів призводить до того, щзо аудиторський висновок виступає ще й джерелом інформації, щчо не представлена у фінансовій звітності. Охарактеризовано, щуо сучасний аудиторський звіт (висновок) є складовою частиною інформаційного ресурсу про господарську діяльність підприємства, щзо у иілому дає змогу підвищчити його якісні характеристики та задовольнити інформаційні потреби зацікавлених сторін, щуо в результаті призводить до зниження або ж уникнення інформачійної асиметрї на ринках капіталів.

Ключові слова: фальсифікації, економічні ресурси, аудит, аудиторські фірми, економічні злочини.

\section{Hrytsyshen Dymytrii, Prokopenko Zhanna, Kochyn Tetiana, Opanasiuk Andrii. Development of audit as an anti-counterfeiting tool}

The article proves that the analysis of the current stage of development of auditing in the world indicates the lack of common global approaches to the regulation of auditing. It is described that each country develops its own approaches to the management of audit regulation and sets specific requirements for the activities of audit firms. It is noted that the main characteristics of modern audit are the establishment of requirements for human resources of the audit firm. It is proved that in fact today the audit report (conclusion) should confirm the quality of financial statements as a careful tool for informing users to make management decisions. It is proved that by expanding the audit procedures, in particular the use of analytical procedures, allows to speak on the audit report (conclusion) as part of the information resource. 
It is characterized that the information resource of economic and economic activity is a set of information contained in the financial statements and audit report (conclusion). It is proved that it is necessary to review the approaches to the audit report (conclusion) and determine its place in the structure of the information resource.

It is specified that the audit report can be viewed from several positions: first, as a result of the auditor's work. In this context, it is also necessary to determine the audit opinion and the result of the implementation of the contractual relationship for the audit of financial statements; secondly, a document that contains the auditor's opinion on the financial statements of the surveyed enterprise and guarantees confidence to interested users. It is proved that it is necessary to change the approach to the audit report (conclusion) as a document confirming the reliability of financial statements, because the change in user requests leads to the fact that the audit report is also a source of information not presented in the financial statements. It is characterized that the modern audit report (conclusion) is a component of the information resource about the economic activity of the enterprise, which in general allows improving its quality characteristics and meeting the information needs of stakeholders, which leads to reduction or avoidance of information asymmetry in capital markets.

Key words: falsifications, economic resources, audit, audit firms, economic crimes.

Актуальність дослідження. У сучасних умовах господарювання варто змінити акцент дослідження аудиту від інструменту підтвердження достовірності фінансової звітності та надання впевненості користувачам до інструменту формування якісного інформаційного ресурсу. Так, сьогодні користувачі бухгалтерського обліку все більше наголошують на необхідності оприлюднення саме якісної інформації, а іiі достовірність $€$ не еталоном, а лише одним зі складників властивостей якості інформації.

Аналіз останніх досліджень. Сучасний стан наукових досліджень у сфері бухгалтерського обліку та аудиту характеризується вагомим внеском у розвиток теорії та методології аудиту вітчизняних учених, зокрема: О.Р. Антонюк, В.П. Бондаря, Г.І. Давидова, Н.І. Дорош, С.Я. Зубілевич, М.Д. Корінька, Є.В. Мниха, Н.М. Проскуріної, О.А. Петрик, О.Ю. Редька, К.І. Редченка, В.І. Рудницького, В.В. Рядської, Б.Ф. Усача, Н.С. Шалімової, О.Л. Шерстюка, І.М. Дмитренко, І.К. Дрозд, Т.О. Каменської, К.О. Назарової, О.В. Сметанка та ін. Зазначені вчені присвятили свої праці розвитку теорії аудиту як науки, впровадженню незалежного аудиту як процесу трансформації системи контролю в країнах пострадянського простору, розвитку аудиторських процедур, упровадженню міжнародних стандартів аудиту, застосуванню етичних принципів у діяльності аудитора, інституційному забезпеченню аудиту та іншім проблемним питанням. Серед зарубіжних учених питання розвитку аудиту значно відрізняються, адже становлення ринкових відносин відбулося значно раніше, що й зумовило власне виникнення аудиту як такого. Так, основоположними результатами наукових досліджень, які визначають витоки аудиту як функціональної науки у світі, $є$ праці Д. Блутфілд, Дж. Шекман, П. Кармона, Дж. Бігус, Р.-К. Зіммерман, І.В. Аверчева, Н.Г. Айрапетової, Я. Алвера, Н.А. Бреславцевої, В.Г. Гетьмана, Т.Д. Варфілда, Дж.Дж. Вейгандта, С.Дж. Грея, Т.Ю. Дружиловської, Д.Е. Кізо, В.В. Ковальова, М.І. Кутера, М.Р. Метьюса, К. Ноубса, В.Ф. Палія, Д.О. Панкова, Н.В. Парушиної, М.Х.Б. Перероя, Р. Паркера, М.Л. Пятова, О.В. Рожнової, Я.В. Соколова, Е.С. Хендріксена, Т.В. Федоровича, О.М. Хоріна, Л.Ф. Шилової, Л.З. Шнейдмана та ін.

Виклад основного матеріалу. Фактично сьогодні аудиторський звіт (висновок) має підтверджувати якість фінансової звітності як важливого інструменту інформування користувачів для прийняття управлінських рішень. Своєю чергою, розширення аудиторських процедур, зокрема використання аналітичних процедур, дає змогу вести мову про аудиторський звіт (висновок) як складову частину інформаційного ресурсу. Інформаційним ресурсом про економічну дійсність та господарську діяльність виступає сукупність інформації, що міститься у фінансовій звітності та аудиторському звіті (висновку). Отже, варто переглянути підходи до аудиторського звіту (висновку) та визначити його місце у структурі інформаційного ресурсу.

«Згідно з чинним законодавством, за результатами проведеного аудиту аудитор повинен надавати своєму клієнтові (замовнику аудиту) підсумковий документ - аудиторський висновок (звіт). Він складається 3 дотриманням установлених норм та стандартів і має містити підтвердження або аргументовану відмову від підтвердження достовірності, повноти та відповідності чинному законодавству фінансової звітності підприємства-клієнта. Перед складанням аудиторського висновку (звіту) аудитор остаточно оцінює аргументованість своїх тверджень і доказів» [4].

«Головною метою аудиту є вираження думки про достовірність фінансової звітності і відповідність порядку ведення бухгалтерського обліку законодавству України. Саме аудит сприяє запобіганню фінансовим порушенням на підприємстві, підробкам, випадковим помилкам, недолікам в організації обліку» [2, с. 411].

Аудиторський звіт (висновок) є особливим складником процесу аудиту фінансової звітності. Його важливість полягає у тому, що він містить думку аудитора та іії підтвердження щодо достовірності показників фінансової звітності підприємства. 
«Важливість аудиторського звіту (висновку) як одного 3 основних підсумкових документів роботи аудитора $є$ безумовною. Від якості його складання залежить рівень достовірності, об'єктивності і повноти інформації про підприємство, що перевіряється, яка подається зовнішнім і внутрішнім користувачам» [4]. «Складання аудиторського звіту є одним із найвідповідальніших складників аудиторського процесу, оскільки формуються підсумки виконаних аудиторських процедур, узагальнюються виявлені помилки, визначається їх сукупний вплив на фінансову звітність і висловлюється думка аудитора щодо іiі достовірності, повноти відповідності чинному законодавству. Аудиторський звіт (висновок) - це «продукт» праці аудитора. Висловлюючи свою думку, аудитор забезпечує впевненість користувачів інформації в тому, що інформація, наведена у звітності, є достовірною» [3].

Із даного приводу вітчизняна вчена О.А. Петрик указує: «Ефективність організації незалежного аудиту визначається плануванням, документуванням, відповідальністю за аудиторський висновок, взаємодією аудиторів, залученням експертів, повним та об'єктивним інформуванням клієнтів, контролем якості роботи аудитора, договірними відносинами, взаємодією з клієнтом у процесі перевірки, додержанням принципів професійної етики, а також дотриманням послідовності процесу аудиту (чотири останніх принципи запропоновано особисто автором)» [9].

Аудиторський висновок є особливим складником як власне аудиту, так і системи інформування зацікавлених осіб. Д.В. Долбнєва вказує, що «основним результатом роботи аудитора та одним із найвідповідальніших етапів аудиту (виконання аудиторських процедур) $є$ аудиторський висновок, який складається на завершальній стадії аудиту і повинен містити у собі виявлені помилки, визначення та узагальнення їх сукупного впливу на фінансову звітність клієнта (замовника). В аудиторському висновку висловлюється незалежна думка аудитора щодо достовірності фінансової звітності, iї повноти та відповідності чинному законодавству. Саме тому від розуміння аудитором сутності та вимог до складання аудиторського висновку залежать його якість та об'єктивність, а також здатність задовольнити інформаційні потреби зовнішніх і внутрішніх користувачів» [4].

Відповідно до Закону України «Про аудит фінансової звітності та аудиторську діяльність», звіт аудитора - це «документ, підготовлений суб'єктом аудиторської діяльності за результатами аудиту фінансової звітності (консолідованої фінансової звітності) відповідно до міжнародних стандартів аудиту та вимог цього Закону» [9].

Аудиторський звіт можна розглядати з декількох позицій:

- по-перше, результат роботи аудитора. Із цього погляду оцінюється власне діяльність аудитора або групи аудиторів. Документ складається за результатами роботи аудиторів у межах певного завдання;

- по-друге, результат виконання договірних відносин. У даному контексті варто також визначати аудиторський висновок як результат виконання договірних відносин щодо аудиту фінансової звітності;

- по-третє, документ, що містить думку аудитора щодо фінансової звітності досліджуваного підприємства та гарантує надання впевненості зацікавленим користувачам.

Усі зазначені складники у цілому формують уявлення про аудиторський висновок. Варто зазначити, що зазначені складники враховано як у вітчизняному аудиторському законодавстві, так і в Міжнародних стандартах аудиту. «Приведення вітчизняних нормативних актів із питань регулювання порядку проведення аудиту, у т. ч. і складання аудиторського висновку (звіту) до МСА, відбувалося у чотири етапи: I етап: прийняття Національних нормативів аудиту, затверджених Рішенням АПУ № 73 від 18.12.1998; II етап: прийняття Рішення АПУ від 18 квітня 2003 р. № 122 «Про порядок застосування в Україні Міжнародних стандартів аудиту». Стандарти аудиту та етики Міжнародної федерації бухгалтерів прийняті як Національні стандарти аудиту та набрали чинності 301 січня 2004 р. Згодом було прийнято Рішення АПУ від 30.10.2003 «Про затвердження Національних нормативів аудиту України та Кодексу професійної етики аудиторів України» від 18 грудня 1998 р. №73 вважати таким, що втратило чинність з 1 січня 2004 року»; III етап: прийняття Рішення АПУ від 30.11.2006 «Про застосування Міжнародних стандартів аудиту видання 2006 року» як Національних стандартів аудиту, що введені в дію 301 січня 2007 р.; IV етап: прийняття Рішення АПУ від 31.03.2011 229/7 «Про застосування Міжнародних стандартів аудиту видання 2010 р.» як Національних стандартів аудиту та введені в дію з 01 квітня 2011 р.» [4].

На сучасному етапі складання та оприлюднення аудиторського висновку регулюється Міжнародними стандартами аудиту. Вивчення праць учених (Л.В. Гуцаленко, Я.В. Сидорук, І.М. Пожарицька) щодо даного питання дає змогу систематизувати вимоги міжнародних стандартів до аудиторського звіту (висновку) (табл. 1). 
Характеристика міжнародних стандартів аудиту щодо регулювання складання аудиторського звіту (висновку)

\begin{tabular}{|c|c|c|c|}
\hline $\begin{array}{c}\text { Назва } \\
\text { розділу }\end{array}$ & $\begin{array}{l}\text { Назва і номер } \\
\text { стандарту }\end{array}$ & $\begin{array}{c}\text { Назва } \\
\text { документу }\end{array}$ & $\begin{array}{c}\text { Типи } \\
\text { аудиторської Думки }\end{array}$ \\
\hline \multicolumn{4}{|c|}{$\begin{array}{l}\text { Міжнародні стандарти аудиту та положення } \\
\text { з міюннародної практики аудиту (вид. } 2003 \text { р.) [7] }\end{array}$} \\
\hline $\begin{array}{l}\text { 700-799 Ауди- } \\
\text { торські думки } \\
\text { звітність }\end{array}$ & $\begin{array}{l}\text { 700А Аудиторський } \\
\text { висновок про фінансову } \\
\text { звітність }\end{array}$ & $\begin{array}{l}\text { Аудиторський } \\
\text { висновок }\end{array}$ & $\begin{array}{l}\text { - безумовно-позитивний висновок; } \\
\text { - модифіковані висновки (умовно-пози- } \\
\text { тивна думка, відмова від висловлення } \\
\text { думки, негативна думка) }\end{array}$ \\
\hline \multicolumn{4}{|c|}{$\begin{array}{l}\text { Міжнародні стандарти аудиту, надання } \\
\text { впевненості та етики (вид. } 2006 \text { р.) [5] }\end{array}$} \\
\hline $\begin{array}{l}\text { 700-799 Аудитор- } \\
\text { ські висновки та } \\
\text { звітність }\end{array}$ & $\begin{array}{l}700 \text { Висновок незалежного } \\
\text { аудитора щодо повного } \\
\text { пакету фінансових звітів } \\
\text { загального призначення }\end{array}$ & $\begin{array}{l}\text { Висновок незалеж- } \\
\text { ного аудитора }\end{array}$ & $\begin{array}{l}\text { - безумовно-позитивний висновок; } \\
\text { - модифіковані висновки (умовно-пози- } \\
\text { тивна думка, відмова від висловлення } \\
\text { думки, негативна думка) }\end{array}$ \\
\hline \multicolumn{4}{|c|}{$\begin{array}{l}\text { Міжннародні стандарти контролю якості, аудиту, огляду, } \\
\text { іншого надання впевненості та супутніх послуг (вид. } 2012 \text { р.) [6] }\end{array}$} \\
\hline $\begin{array}{l}\text { 700-799 Аудитор- } \\
\text { ські висновки та } \\
\text { звітність }\end{array}$ & $\begin{array}{l}\text { МСА } 700 \text { «Формулювання } \\
\text { думки та надання звіту } \\
\text { щодо фінансової звітності» }\end{array}$ & $\begin{array}{l}\text { Звіт незалежного } \\
\text { аудитора }\end{array}$ & $\begin{array}{l}\text { - немодифікована думка; } \\
\text { - модифіковані думки (умовно-пози- } \\
\text { тивна думка, негативна думка, відмова від } \\
\text { висловлення думки) }\end{array}$ \\
\hline \multicolumn{4}{|c|}{$\begin{array}{l}\text { Міжнародні стандарти контролю якості, аудиту, огляду, } i \\
\text { ншого надання впевненості та супутніх послуг (вид. } 2015 \text { р.) [8] }\end{array}$} \\
\hline $\begin{array}{l}\text { 700-799 Аудитор- } \\
\text { ські висновки та } \\
\text { звітність }\end{array}$ & $\begin{array}{l}\text { МСА } 700 \text { «Формування } \\
\text { думки та складання звіту } \\
\text { щодо фінансової звітності» }\end{array}$ & Звіт аудитора & $\begin{array}{l}\text { - немодифікована думка; } \\
\text { - модифікована думка (думка із засте- } \\
\text { реженням, негативна думка, відмова від } \\
\text { висловлення думки) }\end{array}$ \\
\hline
\end{tabular}

Відповідно до Закону України «Про аудит фінансової звітності та аудиторську діяльність», «аудиторський звіт передбачає надання впевненості користувачам шляхом висловлення незалежної думки аудитора про відповідність у всіх суттєвих аспектах фінансової звітності та/або консолідованої фінансової звітності вимогам НП(С)БО, МСФЗ або іншим вимогам. Аудиторський звіт підписує аудитор, який провадить аудиторську діяльність як фізична особа - підприємець або провадить незалежну професійну діяльність у разі проведення ним аудиту одноосібно або щонайменше як ключовий партнер у разі проведення аудиту аудиторською фірмою. У разі одночасного залучення декількох суб'єктів аудиторської діяльності аудиторський звіт підписується всіма аудиторами, а від аудиторської фірми - щонайменше ключовим партнером. Особа, яка підписала аудиторський звіт, зазначає дату підписання» [1].

Власне, як зазначений закон, так і Міжнародні стандарти висувають сукупність вимог до звіту аудитора. Вимоги стосовно структури та формату звіту аудитора містяться в таких стандартах редакції 2016-2017 рр. «Міжнародних стандартів контролю якості, аудиту, огляду, іншого надання впевненості та супутніх послуг»:

- 700 «Формування думки та складання звіту щодо фінансової звітності»;

- 705 «Модифікації думки у звіті незалежного аудитора»;

- 701 «Повідомлення інформації з ключових питань аудиту в звіті незалежного аудитора»;

- 706 «Пояснювальні параграфи та параграфи з інших питань у звіті незалежного аудитора»;

- 710 «Порівняльна інформація - відповідні показники і порівняльна фінансова звітність»;

- 720 «Відповідальність аудитора щодо іншої інформації»;

- 570 «Безперервність діяльності».

Варто зауважити, що Міжнародні стандарти аудиту та Закон України «Про аудит фінансової звітності та аудиторську діяльність» передбачають різну структуру аудиторського звіту (табл. 2). Відповідно до зазначених стандартів, для того щоб аудитор сформував свою думку щодо фінансової звітності, він повинен:

«1) висновок аудитора відповідно до МСА 330 щодо того, чи були отримані прийнятні аудиторські докази в достатньому обсязі;

2) висновок аудитора відповідно до МСА 450 щодо суттєвості невиправлених викривлень (окремо або в сукупності); 
3) оцінювання:

3.1. чи складена фінансова звітність в усіх суттєвих аспектах згідно з вимогами застосовної концептуальної основи фінансового звітування;

3.2. якщо фінансова звітність складена відповідно до концептуальної основи достовірного подання, то оцінювання також повинно включати оцінювання того, чи забезпечено достовірне ії подання;

3.3. чи зроблено у фінансовій звітності належне посилання на застосовну концептуальну основу фінансового звітування або пї описання».

На основі зазначеного аудитор формує думку, яка, відповідно до Закону України «Про аудит фінансової звітності та аудиторську діяльність», має такі види:

1. немодифікована;

2. модифікована:

2.1. думка із застереженням;

2.2. негативна;

2.3. відмова від висловлення думки.

Таблиця 2

Структура звіту аудитора за Міжнародними стандарти аудиту та Законом України «Про аудит фінансової звітності та аудиторську діяльність»

\begin{tabular}{|c|c|}
\hline $\begin{array}{c}\text { Закон України «Про аудит фінансової звітності } \\
\text { та аудиторську діяльність» }\end{array}$ & $\begin{array}{c}\text { Міжнародні } \\
\text { стандарти аудиту }\end{array}$ \\
\hline $\begin{array}{l}\text { 1. Повне найменування юридичної особи. } \\
\text { 1.1 Склад фінансової звітності або консолідованої } \\
\text { фінансової звітності. } \\
\text { 1.2 Звітний період та дата, на яку вона складена. } \\
\text { 1.3 Відповідно до яких стандартів (МСФ3, П(С)БО, } \\
\text { ін.) складено фінансову звітність. } \\
\text { 2. Твердження про застосування міжнародних стан- } \\
\text { дартів аудиту (МСА). } \\
\text { 3. Чітко висловлена думка аудитора немодифікована } \\
\text { або модифікована. } \\
\text { 4. Окремі питання, на які САД уважає за доцільне } \\
\text { звернути увагу, але які не вплинули на висловлену } \\
\text { думку аудитора. } \\
\text { 5. Про узгодженість звіту про управління; Про наяв- } \\
\text { ність суттєвих викривлень у звіті про управління та їх } \\
\text { характер. } \\
\text { 6. Суттєву невизначеність щодо безперервної діяль- } \\
\text { ності (за МСА 570), у разі наявності такої невизначе- } \\
\text { ності. } \\
\text { 7. Основні відомості про САД, що провів аудит (повне } \\
\text { найменування, місцезнаходження, інформація про } \\
\text { включення до Реєстру). }\end{array}$ & $\begin{array}{l}\text { 1. Назва. } \\
\text { 2. Адресат. } \\
\text { І Звіт щодо аудиту фінансової звітності. } \\
\text { 3. Думка аудитора. } \\
\text { 4. Основа для думки. } \\
\text { 5. Безперервність діяльності (там, де це застосовно, } \\
\text { аудитор повинен звітувати відповідно до вимог } \\
\text { МСА 570). } \\
\text { 6. Ключові питання аудиту. } \\
\text { 7. Інша інформація. } \\
\text { 8. Відповідальність управлінського персоналу за } \\
\text { фінансову звітність. } \\
\text { 9. Відповідальність аудитора за аудит фінансової звіт- } \\
\text { ності. } \\
\text { ІІ Звіт щодо вимог інших законодавчих та норматив- } \\
\text { них актів. } \\
\text { 10. Повне ім’я партнера із завдання. } \\
\text { 11. Підпис аудитора. } \\
\text { 12. Адреса аудитора. }\end{array}$ \\
\hline
\end{tabular}

Такий поділ аудиторської думки зумовлений тим, чи розкриває фінансова звітність підприємства в усіх суттєвих аспектах достовірно та об'єктивно фінансову інформацію згідно з міжнародними стандартами фінансової звітності (MCФ3 (IAS / IFRS)) або національними положеннями (стандартами) бухгалтерського обліку (НП(С)БО, П(С)БО) та відповідає вимогам законодавства, зокрема господарського, податкового, бюджетного, екологічного та іншого галузевого.

В Україні стан фінансової звітності можна прослідкувати за видами аудиторських звітів, що надали представництва компаній великої аудиторської четвірки (ТОВ «Ернст енд Янг аудиторські послуги», ПрАТ «Делойт енд Туш Юкрейніан Сервісез Компані», ТзОВ «Аудиторська фірма «ПрайсвотерхаусКуперс (Аудит)», ПАТ «КПМГ АУДИТ»). Зокрема, нами проаналізовано аудиторські звіти, що сформовано зазначеними компаніями протягом трьох років (2015-2017рр.) щодо фінансової звітності підприємств, що становлять суспільний інтерес («підприємства, що становлять суспільний інтерес, - підприємства емітенти цінних паперів, цінні папери яких допущені до торгів на фондових біржах або щодо цінних паперів яких здійснено публічну пропозицію, банки, страховики, недержавні пенсійні фонди, інші фінансові установи (окрім інших фінансових установ та недержавних пенсійних фондів, що належать до мікропідприємств та малих підприємств) та підприємства, які, відповідно до цього Закону, належать 
до великих підприємств» [11]). Зокрема, проаналізовані звіти стосуються підприємств різних галузей національного господарства (банківські та фінансові установи, промислові підприємства, підприємства сфери зв'язку, транспортні підприємства та підприємства інших галузей). Результати проведеного аналізу аудиторських звітів представлено в табл. 3.

Таблиця 3

Характеристика аудиторських висновків «великої четвірки» щодо фінансової звітності підприємства, що становлять суспільний інтерес

\begin{tabular}{|c|c|c|c|}
\hline Рік проведення аудиту & 2015 p. & 2016 p. & 2017 p. \\
\hline 1 & 2 & 3 & 4 \\
\hline \multicolumn{4}{|l|}{ ТОВ «Ернст енд Янг аудиторські послуги» } \\
\hline ПАТ «Укртелеком» & 01-(умовно-позитивна) & 01-(умовно-позитивна) & 02-(із застереженням) \\
\hline ПАТ «Укргазбанк» & 01-(умовно-позитивна) & 01-(умовно-позитивна) & 01-(умовно-позитивна) \\
\hline ПАТ «Укрзалізниця» & 01-(умовно-позитивна) & 02-(із застереженням) & 02-(із застереженням) \\
\hline ПАТ «Турбоатом» & 01-(умовно-позитивна) & 02-(із застереженням) & 02-(із застереженням) \\
\hline ПАТ «Рено Україна» & 01-(умовно-позитивна) & 01-(умовно-позитивна) & 02-(із застереженням) \\
\hline ПАТ «Природні Ресурси» & 01-(умовно-позитивна) & 01-(умовно-позитивна) & 01-(умовно-позитивна) \\
\hline АТ КБ «ПУМБ» & 01-(умовно-позитивна) & 02-(із застереженням) & 01-(умовно-позитивна) \\
\hline ПАТ «Одеський припортовий завод» & 01-(умовно-позитивна) & 01-(умовно-позитивна) & 02-(із застереженням) \\
\hline ПАТ «Дікергофф Цемент Україна» & 01-(умовно-позитивна) & 02-(із застереженням) & 01-(умовно-позитивна) \\
\hline $\begin{array}{l}\text { ПАТ «Державний Експортно-Імпортний } \\
\text { Банк України» }\end{array}$ & 01-(умовно-позитивна) & 01-(умовно-позитивна) & 01-(умовно-позитивна) \\
\hline \multicolumn{4}{|c|}{ Приватне акціонерне товариство «Делойт енд Туи Юкрейніан Сервісез Компані» } \\
\hline $\begin{array}{l}\text { ПАТ «Рубіжанський картонний-тарний } \\
\text { комбінат» }\end{array}$ & 01-(умовно-позитивна) & 02-(із застереженням) & 01-(умовно-позитивна) \\
\hline НАК «Нафтогаз» & 01-(умовно-позитивна) & 02-(із застереженням) & 02-(із застереженням) \\
\hline ПАТ «ВФ Україна» & 01-(умовно-позитивна) & 01-(умовно-позитивна) & 01-(умовно-позитивна) \\
\hline ПАТ «Фармак» & 01-(умовно-позитивна) & 01-(умовно-позитивна) & 01-(умовно-позитивна) \\
\hline АТ «Укргазвидобування» & - & 01-(умовно-позитивна) & 02-(із застереженням) \\
\hline ПАТ «Банк Восток» & 01-(умовно-позитивна) & 01-(умовно-позитивна) & 01-(умовно-позитивна) \\
\hline АТ «Піреус Банк МКБ» & 01-(умовно-позитивна) & 01-(умовно-позитивна) & 01-(умовно-позитивна) \\
\hline $\begin{array}{l}\text { ПАТ «Розрахунковий центр з обслугову- } \\
\text { вання договорів на фінансових ринках» }\end{array}$ & 01-(умовно-позитивна) & 01-(умовно-позитивна) & 02-(із застереженням) \\
\hline ПАТ «Метлайф» & 01-(умовно-позитивна) & 01-(умовно-позитивна) & 01-(умовно-позитивна) \\
\hline ПАТ «Арселор Міттал Кривий Ріг» & 01-(умовно-позитивна) & 01-(умовно-позитивна) & 01-(умовно-позитивна) \\
\hline АТ «Агропросперіс Банк» & 01-(умовно-позитивна) & 01-(умовно-позитивна) & 01-(умовно-позитивна) \\
\hline ПАТ «БТА Банк» & 01-(умовно-позитивна) & 01-(умовно-позитивна) & 02-(із застереженням) \\
\hline ПАТ «Укрсоцбанк» & 01-(умовно-позитивна) & 02-(із застереженням) & 02-(із застереженням) \\
\hline АТ «ОТП Банк» & 01-(умовно-позитивна) & 01-(умовно-позитивна) & 01-(умовно-позитивна) \\
\hline \multicolumn{4}{|c|}{ Товариство з обмеженою відповідальністю Аудиторська фірма «Прайсвотерхаускуперс (Аудит)» } \\
\hline АТ «КБ «ПриватБанк» & 01-(умовно-позитивна) & 02-(із застереженням) & 02-(із застереженням) \\
\hline АТ «Креді Агріколь банк» & 01-(умовно-позитивна) & 01-(умовно-позитивна) & 01-(умовно-позитивна) \\
\hline ПрАТ «Аіг Україна Страхова Ком & 01-(умовно-позитивна) & 01-(умовно-позитивна) & 01-(умовно-позитивна) \\
\hline $\begin{array}{l}\text { ПАТ «Славутський комбінат } \\
\text { «Будфарфор» }\end{array}$ & 01-(умовно-позитивна) & 01-(умовно-позитивна) & 02-(із застереженням) \\
\hline ПАТ «Карлсберг Україна» & 01-(умовно-позитивна) & 01-(умовно-позитивна) & 01-(умовно-позитивна) \\
\hline $\begin{array}{l}\text { ПАТ «Імперіал Тобакко Продакшн } \\
\text { Україна» }\end{array}$ & 01-(умовно-позитивна) & 01-(умовно-позитивна) & 02-(із застереженням) \\
\hline ПАТ «Київстар» & 01-(умовно-позитивна) & 01-(умовно-позитивна) & 01-(умовно-позитивна) \\
\hline ПАТ «Монделіс Україна» & 01-(умовно-позитивна) & 01-(умовно-позитивна) & 02-(із застереженням) \\
\hline ПАТ «Філіп Морріс Україна» & 01-(умовно-позитивна) & 01-(умовно-позитивна) & 01-(умовно-позитивна) \\
\hline ПАТ «СКФ Україна» & 01-(умовно-позитивна) & 01-(умовно-позитивна) & 01-(умовно-позитивна) \\
\hline \multicolumn{4}{|l|}{ ПАТ “КПМГ АУДИТ” } \\
\hline ПАТ «Астра Банк» & 01-(умовно-позитивна) & 01-(умовно-позитивна) & 01-(умовно-позитивна) \\
\hline ПАТ «Консюмерс-Скло-Зоря» & 01-(умовно-позитивна) & 01-(умовно-позитивна) & 02-(із застереженням) \\
\hline АТ «Кредобанк» & 01-(умовно-позитивна) & 01-(умовно-позитивна) & 01-(умовно-позитивна) \\
\hline
\end{tabular}


Закінчення таблиці 3

\begin{tabular}{|c|c|c|c|}
\hline 1 & 2 & 3 & 4 \\
\hline АТ «Укрсоцбанк» & 01-(умовно-позитивна) & 02-(із застереженням) & 02-(із застереженням) \\
\hline $\begin{array}{l}\text { ПАТ «Запорізький металургійний } \\
\text { комбінат «Запоріжсталь» }\end{array}$ & 01-(умовно-позитивна) & 01-(умовно-позитивна) & 01-(умовно-позитивна) \\
\hline ПАТ «Вімм-Білль-Данн Україна» & 01-(умовно-позитивна) & 01-(умовно-позитивна) & 02-(із застереженням) \\
\hline ПАТ «Страхова компанія «ПЗУ Україан» & 01-(умовно-позитивна) & 01-(умовно-позитивна) & 01-(умовно-позитивна) \\
\hline АТ «Прокредит Банк» & 01-(умовно-позитивна) & 01-(умовно-позитивна) & 01-(умовно-позитивна) \\
\hline AT «Правекс Банк» & 01-(умовно-позитивна) & 01-(умовно-позитивна) & 01-(умовно-позитивна) \\
\hline АТ «Райффайзен Банк Аваль» & 01-(умовно-позитивна) & 01-(умовно-позитивна) & 01-(умовно-позитивна) \\
\hline ПАТ «Свроцемент-Україна» & 01-(умовно-позитивна) & 01-(умовно-позитивна) & 02-(із застереженням) \\
\hline $\begin{array}{l}\text { ПАТ «Український Процесінгований } \\
\text { Центр» }\end{array}$ & 01-(умовно-позитивна) & 01-(умовно-позитивна) & 01-(умовно-позитивна) \\
\hline ПАТ «Ясинівський коксохімічний завод» & $\begin{array}{l}\text { 04- (відмова від } \\
\text { висловлення думки) }\end{array}$ & 03-(негативна) & 03-(негативна) \\
\hline
\end{tabular}

На основі отриманих результатів аналізу аудиторських звітів, що складені аудиторами, представництв компаній великої аудиторської четвірки щодо фінансової звітності підприємств, що становлять суспільний інтерес, можна зробити такі висновки:

- аудит фінансової звітності підприємств, що становлять суспільний інтерес, який буз здійснений ТОВ «Ернст енд Янг аудиторські послуги» у 2015 р., супроводжувався модифікованим аудиторським звітом, а саме умовно-позитивною думкою. Тобто фінансова звітність жодного з клієнтів не супроводжувалася позитивною немодифікованою аудиторською думкою. Аудит фінансової звітності зазначених підприємств, який був здійснений компанією ТОВ «Ернст енд Янг аудиторські послуги» в 2016 р., указує на погіршення якості оприлюдненої фінансової інформації. Зокрема, висловлено модифіковану думку із застереженнями щодо фінансової звітності таких підприємств: ПАТ «Укрзалізниця», ПАТ «Турбоатом», АТ КБ «ПУМБ», ПАТ «Дікергофф Цемент Україна». Щодо інших підприємств вид аудиторського звіту є ідентичним до звітів за 2015 р. Фінансова звітність за 2017 звітний рік покращилася 3 модифікованої думки аудитора із застереженням до умовно-позитивної у АТ «КБ «ПУМБ» та ПАТ «Дікергофф Цемент Україна». Якість фінансової звітності, відповідно до звіту аудитора, зменшилася у таких підприємствах, як ПАТ «Укртелеком», ПАТ «Рено Україна», ПАТ «Одеський припортовий завод»;

- фінансова звітність клієнтів ПрАТ «Делойт енд Туш Юкрейніан Сервісез Компані» характеризується умовно-позитивною думкою аудитора за звітний період 2015 р. Ситуація змінилася 2016 р., зокрема модифікований аудиторський звіт із думкою аудитора із застереженням характерна для фінансової звітності таких підприємств: ПАТ «Рубіжанський картонний-тарний комбінат», НАК «Нафтогаз», ПАТ «Укрсоцбанк». Звітність усіх інших підприємств характеризується думкою аудитора як умовнопозитивна. У 2017 р. якість фінансової звітності на думку аудитора покращилася у ПАТ «Рубіжанський картонний-тарний комбінат», а погіршилася у АТ «Укргазвидобування», ПАТ «Розрахунковий центр 3 обслуговування договорів на фінансових ринках», ПАТ «БТА Банк». Аудиторська думка щодо звітності усіх інших підприємств - клієнтів ПрАТ «Делойт енд Туш Юкрейніан Сервісез Компані» залишилася незмінною;

- умовно позитивна думка про фінансову звітність за 2016 р. підприємств, що мають суспільний інтерес, характерна для всіх клієнтів ТзОВ «Аудиторська фірма «ПрайсвотерхаусКуперс (Аудит)». Ситуація змінилася на гірше (модифікована думка аудитора із застереженнями) лише для одного клієнта, а саме АТ «КБ «ПриватБанк». Для даного клієнта аудиторської фірми ідентична думка характерна і за звітний 2017 р. У 2017 р. модифікована думка аудитора із застереженням стосується фінансової звітності ПАТ «Славутський комбінат «Будфарфор», ПАТ «Імперіал Тобакко Продакшн Україна», ПАТ «Монделіс Україна». Фінансова звітність за 2017 р. усіх інших підприємств-клієнтів характеризуються думкою аудитора як умовно-позитивна;

- за досліджуваний період (2015-2017 звітні роки) ПАТ «КПМГ АУДИТ» мав 13 клієнтів, якіє підприємствами, що становлять суспільний інтерес. Серед досліджуваних підприємств у 2015 р. відмовою від висловлення думки характеризувався аудиторський про фінансову звітність лише одного підприємства - ПАТ «Ясинівський коксохімічний завод». Аудиторські звіти про фінансову звітність за 2015 р. перелічених клієнтів фірми характеризувалися умовно-позитивною думкою аудитора. За 2016 звітний рік ситуація змінилася для АТ «Укрсоцбанк» - із застереженням та ПАТ «Ясинівський коксохімічний 
завод» - негативна. Аналізуючи аудиторські звіти ПАТ «КПМГ АУДИТ» щодо фінансової звітності за 2017 р., варто сказати, що ситуація змінилася для: ПАТ «Консюмерс-Скло-Зоря» - $з$ умовно-позитивної до із застереженням; ПАТ «Вімм-Білль-Данн Україна» - з умовно-позитивної до із застереженням; ПАТ «Свроцемент-Україна» - з умовно-позитивної до із застереженням. Для АТ «Укрсоцбанк» та ПАТ «Ясинівський коксохімічний завод» думка щодо фінансової звітності за 2017 звітний рік залишилася такою самою, як і за 2016 звітний рік, тобто модифікована думка із застереженням та негативна думка аудитора відповідно.

Сьогодні варто змінити підхід до аудиторського звіту (висновку) як до документу, що підтверджує достовірність показників фінансової звітності, адже зміна запитів користувачів призводить до того, що аудиторський висновок виступає ще й джерелом інформації, що не представлена у фінансовій звітності. А розширення складу та змісту аудиторських процедур дає змогу ще й представити інформацію аналітичного характеру, адже сьогодні все більшої актуальності набувають аналітичні процедури в аудиті.

Таким чином, сучасний аудиторський звіт (висновок) $є$ складовою частиною інформаційного ресурсу про господарську діяльність підприємства, що у цілому дає змогу підвищити його якісні характеристики та задовольнити інформаційні потреби зацікавлених сторін, що в результаті призводить до зниження або ж уникнення інформаційної асиметрії на ринках капіталів. Саме методологічний інструментарій аудиту дає змогу сформувати якісний інформаційний ресурс та пізнати економічну дійсність зацікавленими користувачами. У цілому систему бухгалтерського обліку та аудиту можна представити у вигляді інформаційних фільтрів, що є процесом інформаційного моделювання економічної дійсності (рис. 1).

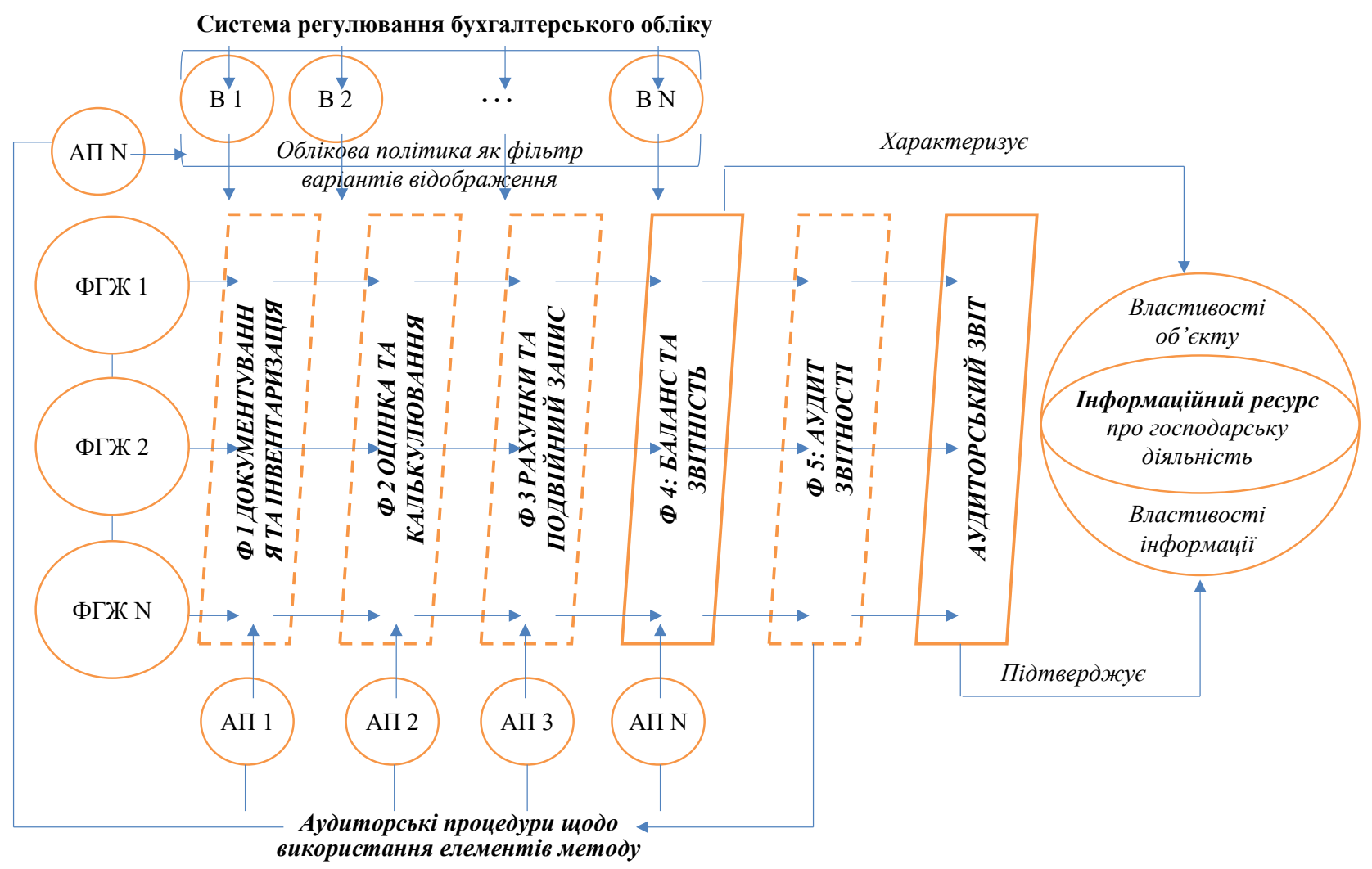

ФГЖ - акт господарського життя; В 1, 2 .. N - варіанти передбачення законодавством; Ф.1 - фільтр, що обмежується реквізитним розширенням документів; Ф. 2 - фільтр, що обмежується методами калькулювання та оцінки; Ф. 3 - фільтр, що обмежується планом рахунків (робочим планом рахунків); Ф. 4 - фільтр, що обмежується попередніми фільтрами та діючими формами; Ф. 5 - фільтр, що обмежується аудиторськими процедурами та потенціалом САД; АП - аудиторські процедури

Рис. 1. Аудит у системі формування якісного інформаційного ресурсу про економічну дійсність

Представлена модель характеризує місце аудиту у формуванні якісного інформаційного ресурсу. Кожний складник представлено як своєрідний фільтр, що виконує відповідні функції, зокрема:

- кожна група елементів методу бухгалтерського обліку виступає своєрідним фільтром, який дає змогу обробляти інформацію про економічну дійсність, яка викладається 3 господарської діяльності 
підприємства. Адже бухгалтерський облік відображає не лише операції, що становлять бізнес-процеси, а й операції, що пов'язані із зовнішнім середовищем, прикладом чого $є$ формування резервів та ін.;

- важливим елементом організації бухгалтерського обліку, що визначає механізм застосування методів як фільтрів даних про господарську діяльність підприємства, є облікова політика. Облікова політика $\epsilon$ інструментом, що визначає вибір варіантів облікового відображення того чи іншого об’єкта бухгалтерського обліку. Від облікової політики залежить увесь процес інформаційного моделювання економічної дійсності. Саме тому під час формування положення про облікову політику враховуються як об'єктивні, так суб'єктивні чинники. До об’єктивних варто віднести: галузеві особливості, специфіку організації виробництва та організаційну і виробничу структуру підприємства; до суб'єктивних - інформаційні запити, стратегію розвитку підприємства, економічну, інвестиційну та маркетингову політику підприємства. Варто також зауважити, що облікова політика виступає об'єктом аудиту, адже аудитор має встановити як ії відповідність законодавству, так і відповідність ії положенням облікового процесу на підприємстві;

- документування та інвентаризація є складниками першого фільтру. Даний фільтр систематизує інформацію, що можливе через відповідні реквізити первинних документів, та підтверджує їх через використання методів інвентаризації. Так, учені для підвищення якості інформації та для врахування усіх властивостей об'єкта бухгалтерського обліку пропонують різні напрями реквізитного розширення існуючих документів та впровадження нових, особливо в контексті появи нових об'єктів бухгалтерського обліку. Аудитор має встановити законність та доцільність такого розширення і порядок використання незатверджених форм первинних документів;

- оцінка та калькулювання виступають другим фільтром даних про об'єкт у системі бухгалтерського обліку. Зазначені методи дають змогу виміряти, оцінити та виразити об'єкт у грошових одиницях. Це можливо через використання дозволених чинним законодавством способів оцінки та методів обліку витрат і калькулювання собівартості продукції, робіт, послуг. Зауважимо, що дані елементи методу є найбільш залежними від суб' єктивного чинника, тобто випливу суб'єкта управління на використання тих чи інших методів та способів оцінки і калькулювання. Вибір методів, що передбачені в чинному законодавстві (національні та міжнародні стандарти бухгалтерського обліку), відбувається під час формування облікової політики підприємства;

- для забезпечення систематизації інформації використовуються такі елементи методу бухгалтерського обліку, як рахунки та подвійний запис. Своєю чергою, рахунки виступають інструментом зберігання інформації про властивості об'єкта бухгалтерського обліку, а подвійний запис - механізмом їі формування на рахунках. Використання зазначених методів як фільтру полягає у тому, що кожне підприємство формує робочий план рахунків, який $є$ інструментом організації аналітичного обліку. Своєю чергою, організація аналітичного обліку залежить від тих властивостей об'єкта облікового відображення, щодо яких $є$ інформаційний запит зацікавлених осіб. Можливості врахування усіх властивостей об'єкта в аналітичному обліку залежать від кадрового потенціалу підприємства та форми ведення бухгалтерського обліку. Так, інформаційно-комп'ютерна система, яка використовується підприємством, дає можливість організації аналітичного обліку в різних розрізах;

- баланс та звітність виступають як фільтром даних про господарську діяльність, так і, власне, складником інформаційного ресурсу. Щодо звітності як фільтру даних, то й цьому контексті варто розглядати не звітність як вид звітного документу про господарську діяльність, а саме процедуру формування показників та звітування. Власне процедура формування показників залежить від організації бухгалтерського обліку на підприємстві та всіх попередніх фільтрів, тобто механізму застосування елементів методу бухгалтерського обліку. Так, кожен елемент методу бухгалтерського обліку фільтрує інформацію про економічну дійсність, що в подальшому залежить від ії відображення на рахунках бухгалтерського обліку, які формують окремі показники фінансової, статистичної, податкової та внутрішньої звітності підприємства. Якість звітності знаходиться в прямій залежності від ефективності механізму застосування елементів методу бухгалтерського обліку. Якщо розглядати фінансову звітність підприємства як складник інформаційного ресурсу, то варто наголосити, що вона має враховувати як властивості об'єкта управління, так і якісні властивості інформації, що залежать від урахування усіх можливих властивостей об'єкта у елементах методу бухгалтерського обліку;

- особливим фільтром інформації про господарську діяльність $\epsilon$ аудит фінансової звітності. У методологічному інструментарії аудиту є сукупність аудиторських процедур, які дають змогу встановити законність господарських операцій, правильність відображення в обліку, відповідність чинному бухгалтерському законодавству та ін. Так, під час планування аудиту відбувається підбір аудиторських процедур щодо оцінки організації бухгалтерського обліку та кожного елементу методу бухгалтерського обліку. Під час аудиту необхідно встановити відповідність організації бухгалтерського обліку чинному 
законодавству та оцінити положення облікової політики на предмет маніпулювання обліковими даними. Зокрема, такі маніпуляції досить часто можна прослідкувати в положенні про облікову політику, яке піддається постійній зміні як перед початком звітного періоду, так і під час нього. Особливу увагу аудитори приділяють таким елементам методу бухгалтерського обліку, як оцінка та калькулювання, адже чинне бухгалтерське законодавство передбачає багато варіантів оцінки різних об'єктів.

Таким чином, вивчаючи механізми використання елементів методу бухгалтерського обліку, треба надати можливість аудиторам установити, наскільки такий механізм дає змогу виявити якісні властивості інформації, що оприлюднюється. А це можливо за умови оцінки, наскільки елементи методу бухгалтерського обліку дають змогу врахувати властивості об'єкта управління та піддаються суб'єктивному впливу як менеджменту підприємства через облікову політику, так і власне бухгалтера через використання професійного судження.

Вищевикладене вказує, що аудиторський висновок є значно важливішим складником, аніж документ, що містить думку аудитора щодо фінансової звітності підприємства. Аудиторський висновок виступає складовою частиною інформаційного ресурсу, що використовують зацікавленні особи для прийняття відповідних рішень. Отже, проведене дослідження характеризує аудит не лише як засіб підтвердження достовірності та надання впевненості, як повноцінний складник інформування зацікавлених сторін. Від аудиту в цілому залежать ринок капіталу та доля окремого підприємства зокрема.

Висновки. Фактично сьогодні аудиторський звіт (висновок) має підтверджувати якість фінансової звітності як важливого інструменту інформування користувачів для прийняття управлінських рішень. Своєю чергою, за допомогою розширення аудиторських процедур, зокрема використання аналітичних процедур, можна вести мову про аудиторський звіт (висновок) як складову частину інформаційного ресурсу. Інформаційним ресурсом про економічну дійсність та господарську діяльність виступає сукупність інформації, що міститься у фінансовій звітності та аудиторському звіті (висновку). Отже, варто переглянути підходи до аудиторського звіту (висновку) та визначити його місце в структурі інформаційного ресурсу.

Аудиторський звіт можна розглядати з декількох позицій: по-перше, як результат роботи аудитора. Із цього погляду оцінюється власне діяльність аудитора або групи аудиторів. Документ складається з результатів роботи аудиторів у межах певного завдання; по-друге, як результат виконання договірних відносин. У цьому контексті варто також визначати аудиторський висновок як результат виконання договірних відносин щодо аудиту фінансової звітності; по-друге, документ містить думку аудитора щодо фінансової звітності досліджуваного підприємства та гарантує надання впевненості зацікавленим користувачам.

Сьогодні варто змінити підхід до аудиторського звіту (висновку) як до документу, що підтверджує достовірність показників фінансової звітності, адже зміна запитів користувачів призводить до того, що аудиторський висновок виступає ще й джерелом інформації, що не представлена у фінансовій звітності. А розширення складу та змісту аудиторських процедур дає змогу ще й представити інформацію аналітичного характеру, адже сьогодні все більшої актуальності набувають аналітичні процедури в аудиті. Сучасний аудиторський звіт (висновок) є складовою частиною інформаційного ресурсу про господарську діяльність підприємства, що у цілому дає змогу підвищити його якісні характеристики та задовольнити інформаційні потреби зацікавлених сторін, що в результаті призводить до зниження або ж уникнення інформаційної асиметрії на ринках капіталів. Саме методологічний інструментарій аудиту дає змогу сформувати якісний інформаційний ресурс та пізнати економічну дійсність зацікавленими користувачами. У цілому систему бухгалтерського обліку та аудиту можна представити у вигляді інформаційних фільтрів, що є процесом інформаційного моделювання економічної дійсності, дана модель характеризує місце аудиту у формуванні якісного інформаційного ресурсу.

Вивчаючи механізми використання елементів методу бухгалтерського обліку, треба надати можливість аудитору встановити, наскільки такий механізм дає змогу виявити якісні властивості інформації, що оприлюднюються. А це можливо за умови оцінки, наскільки елементи методу бухгалтерського обліку дають змогу врахувати властивості об'єкта управління та піддаються суб'єктивному впливу як менеджменту підприємства через облікову політику так і власне бухгалтера через використання професійного судження.

Вищевикладене вказує, що аудиторський висновок є значно важливішим складником, аніж документ, що містить думку аудитора щодо фінансової звітності підприємства. Аудиторський висновок виступає складовою частиною інформаційного ресурсу, що використовують зацікавленні особи для прийняття відповідних рішень. Отже, проведене дослідження характеризує аудит не лише як засіб підтвердження достовірності та надання впевненості, а й як повноцінний складник інформування зацікавлених сторін. Від аудиту в цілому залежать ринок капіталу та доля окремого підприємства зокрема. 
1. Андреев В.Д. Практический аудит. Москва : Экономика, 1994.

2. Голяш І.Д., Будник Л.А. Тенденції розвитку аудиту: ретроспективний погляд та проекція на майбутнє. Науковий вісник Херсонського державного університету. Серія «Економічні науки». 2016. Вип. 17(1). С. $130-133$.

3. Гончаров С.М., Кушнір Н.Б. Тлумачний словник економіста. Київ : Центр навч. літ., 2009. 264 с.

4. Денисюк О.Г. Використання ресурсного потенціалу підприємства та його фінансової складової. Ефективна економіка. 2018. № 2. URL: http://www.economy.nayka.com.ua/pdf/2_2018/38.pdf.

5. Лавренова Е.С. Особенности развития аудита в историческом аспекте с точки зрения американской экономики. URL: https://cyberleninka.ru/article/n/osobennosti-razvitiya-audita-v-istoricheskom-aspekte-s-tochki-zreniya-amerikanskoyekonomiki/viewer.

6. Лазаришина І.Д. Використання економічного аналізу в аудиті. Вісник Тернопільської академії народного господарства. 2002. Вип. 3. С. 192-196.

7. Лазаришина І.Д. Удосконалення методологічних аспектів аналізу відхилень за критерієм суттєвості інформації. Наукові записки. 2003. Вип. 12. С. 119-122.

8. Мельничук Б.В. Еволюція сутності аудиту. Економіка АПК. 2011. № 12. С. 49-57.

9. Обов'язкова ротація аудиторів здійснюється відповідно до встановлених вимог. URL: https://www.pabu.com.ua/ ua/mediacentr-3/profesiini-novyny/1083-oboviazkova-rotatsiia-audytoriv-zdiisniuietsia-vidpovidno-do-vstanovlenykhvymoh.

10. Пантелєєв В.П., Сніжко О.С. Словник бухгалтера та аудитора. Київ : Інформ.-аналіт. агентство, 2009. 239 с.

11. Парацій О. Аналіз фінансового потенціалу підприємства. Наукові записки. 2005. Вип. 14. С. 178-181. 